\title{
A Review of the Properties, Structural Characteristics and Application Potentials of Concrete Containing Wood Waste as Partial Replacement of one of its Constituent Material. ${ }^{1}$
}

\section{${ }^{1 *}$ Christopher FAPOHUNDA ${ }^{2}$ Bolatito AKINBILE and ${ }^{3}$ Akintoye OYELADE}

\author{
${ }^{1}$ Department of Civil Engineering, Federal University, Oye-Ekiti, Nigeria. \\ christopher.fapohunda@fuoye.edu.ng \\ ${ }^{2}$ Department of Building, the Polytechnic Ibadan, Nigeria. \\ timboljekbuild@yahoo.com \\ ${ }^{3}$ Department of Civil and Environmental Engineering, University of Lagos, Nigeria. \\ oyeladeakintoye@yahoo.com \\ *Corresponding Author: christopher.fapohunda@fuoye.edu.ng
}

\begin{abstract}
There is a growing concern that the sustainability of our built environment is being endangered, due to the uncontrolled and massive use of non-renewable natural resources in the production of structural concrete that is used for the construction of her infrastructure. Alternative material resources are being discovered through myriads of research efforts to address this concern. One of such alternative materials is the wood waste material. This paper presents a comprehensive review of properties, structural behaviour and application potentials of concrete containing wood waste, either in form of saw dust ash (SDA) as partial replacement of cement, or saw dust as partial replacement of fine aggregates, or wood aggregates as partial replacement of coarse aggregates. The results of the review showed that, (i) with appropriate mix design, wood waste, either in the form of saw dust ash, or wood aggregate, or saw dust; can be incorporated into the concrete mix to develop structural concrete that satisfies codes requirements, provided the replacement is not above $20 \%$,. and (ii) concrete incorporating SDA has good durability properties against most of the process of deterioration encountered by concrete in service life. Thus, the use of saw dust waste in concrete will enhance sustainable structural and constructional practices.
\end{abstract}

Keywords: Cement, Durability, Saw Dust Ash, Strength, Structural concrete.

\section{INTRODUCTION}

Since Civil engineering as a profession involves the direction of the resources and power in nature for the best interest of mankind [ $1-3]$, it is becoming increasingly clear that integration of sustainable practices and methodologies into Civil engineering in general and structural Engineering in particular, is desirable for the sustainability of the built environment [4]. For the construction of infrastructures in built environment, concrete represents the dominant material used, and it is. surpassed only by water in consumption.

1 Reviewed paper. Submitted: 
The primary materials used in its production are cement, coarse aggregates, fine aggregates and water. But the emissions of greenhouse gases due to structural concrete materials production, especially cement, have become primary global concern, and thus attracting the attention of structural engineers. It is now well-documented, that the contribution of the cement industry to the global emission of greenhouse gases, especially $\mathrm{CO}_{2}$, in the built environment, is over $7 \%$ [5 - 7]; and with the added fact that it is the third most energy-intensive industry [8] raised a serious environmental concern. There is also depletion of natural resources such as aggregate which are mined in the production of concrete, raising the concern of jeopardising the ability of future generation to provide for herself. The steps that are being taking, according to [5], to mitigate the environmental impact of structural design in built environment include: (i) decrease in fuel consumption to attain higher efficiency in production process, (ii) reduction of the rate of clinker production by using mineral admixture replacements, that is, additions of Supplementary Cementing Materials (SCMs) during manufacture or directly through cement replacement at the building site; and looking for alternative sources for the natural aggregates, either manufactured or by-product of industrial processes, or from wastes. In recent times, industrial and agricultural wastes (hitherto valueless and creating disposal problems with potential to pollute the environment) are gradually become the source of both SCMs and aggregates for the production of structural concrete for construction work in built environment. Some SCMs (also called pozzolans) that have been found suitable by researchers as partial replacement of cement include: granulated blast furnace slag - GGBF; [9], silica fume- SF [10], metakaolin - MK [11, 12], fly ash - FA [13], rice husk ash - RHA [14, 15], sawdust ash - SDA [16, 17], etc. The alternative materials found suitable as partial replacement for aggregates include: recycle concrete aggregates [18], crushed concrete, palm kernel shell - PKS [19], blast furnace slag aggregates, expanded perlite (lightweight aggregate), iron ore or crushed steel (heavy weight aggregates), crushed cow bones [20,21], saw dust [22], etc. The usage of saw dust waste in form of saw dust and saw dust ash in concrete production is the subject of this work. Numerous works have been done by researchers [23 - 26] documenting the suitability both of sawdust as partial replacement fine aggregates and saw dust ash (SDA) as partial replacement of cement in structural concrete production. In order to facilitate its usage in built environment, which will help reduce the rate at which cement is being produced and aggregates are being mined, as well as help cleanse the built environment of waste, thus, ensuring ecological balance; it is necessary that all the research work be compiled in a form that contains all necessary information needed by potential users and even researchers to help guide their research efforts. This paper reviews all these works. Previous review works by [27-30] were limited in scope, with each of them barely containing about 25 authors, leaving out the works of several researchers. The purpose of the present effort is to update and compile all research works on wood waste products as it relates to its suitability for the production of structural concrete. It also intends to reveal areas that are yet to be covered, so as to provide a useful direction for further studies, and that, by laying bare its properties and structures, innovative and creative application in conjunction with other compatible materials in the production of structural concrete can be encouraged. This review work is divided into three broad parts: (i) saw dust ash as partial replacement of cement in the production of structural concrete (ii) saw dust as partial replacement of fine aggregates in structural concrete production., and (iii) wood aggregates as partial replacement of coarse aggregates in structural concrete production. 


\section{SAW DUST ASH AS PARTIAL REPLACEMENT OF CEMENT FOR STRUCTURAL CONCRETE PRODUCTION}

\subsection{Production and Properties of Saw Dust Ash}

Properties and characteristics of a material are closely related to that of the parent material and the methods and techniques of its production [15]. This also applies to saw dust ash. Saw Dust Ash (SDA) is produced when saw dust, which is a waste material from the sawmill industry, is burnt into ashes. Combustion of wood and wood products such as: wood chips, bark, saw mill scraps, hard chips rejected from pulping, etc.; as well as combustion of wood biomass for power generation also result in ash as bye-product [27, 31, 32, 33]. In a sense, says [32], SDA can be related to fly ash since fly ash is obtained from coal, which is a fossilized wood. The quality and quantity of SDA produced, according to [28], however depend on some factors like combustion temperature, types and hydrodynamics of the furnace and the species of trees from which the ash is derived. The combustion temperatures of the wood waste influence both the yield and chemical composition of the wood ash. Combustion of the wood waste at temperatures above $500^{\circ} \mathrm{C}$ leads to: (i) the reduction of ash by as much as $45 \%$, (ii) decomposition of carbonates and bicarbonates and thereby decreases the alkalinity of the ash, and (iii) abundance of oxide compounds such as quick lime $(\mathrm{CaO})$, in the chemical phase of ash $[27,34]$. On the other hand, combustion technologies affect the physical properties of ash. It has been revealed that ash produced in a grate fired furnace has a tendency to be coarser in nature and settle inside the chamber as bottom ash, whereas, in more efficient fluidized bed furnaces, the ash produced is finer, with a very low fraction of coarse particles [28]. From the micrographs obtained after SEM analysis, [35] observed that, ash particles collected from different sources exhibits variations in physical characteristics like particle size and shape, and that the method of incineration and quality of raw material supplied for burning also influences the particle size, shape and several other characteristics. The reported specific properties of SDA from structural perspectives included specific gravity, ranging from 2.05 to 2.60 and density ranging from $720-830 \mathrm{~kg} / \mathrm{m}^{3}[1,17,36,37,38,39]$. When these values are compared with the ordinary Portland cement values - 3.12 specific gravity and $1550 \mathrm{~kg} / \mathrm{m} 3$ density - it is obvious that, for a unit weight of cement replaced with SDA, a larger volume will result and consequently lighter concrete (from weight-volume relations). In order to understand the microstructure of wood waste ash, [40] conducted a SEM analysis (Figure 1).
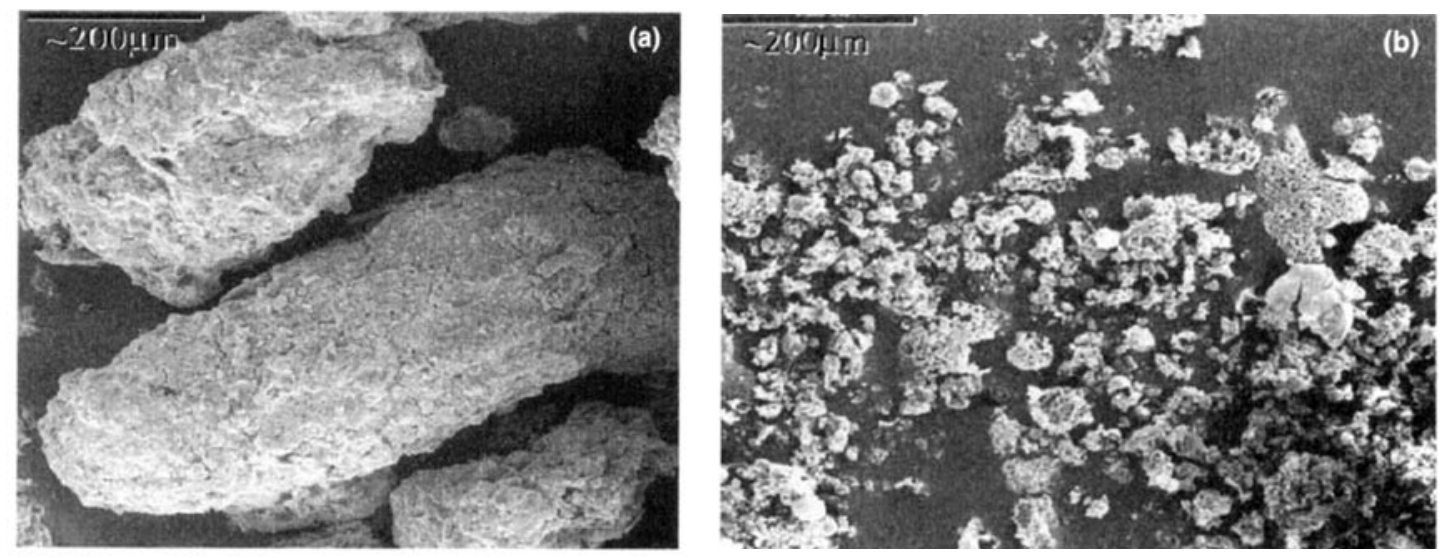

Figure 1. SEM micrographs of typical wood waste ash [40] 
The SEM micrographs showed wood ash as heterogeneous mixture of particles of varying sizes that are generally angular in shapes. Some of the wood ash particles were found to be porous (that is, in cellular form) agglomerated particles. These cellular particles are mostly unburnt or partially burnt wood chips, knots or bark particles. Further investigations by [40], using X-ray diffraction (XRD) for the mineralogical analysis of wood ash, revealed that both amorphous (non-crystalline) and non-amorphous (crystalline) phases were present in the wood ash examined. This observation was also supported by [39].

\subsection{Chemical Properties of SDA}

The chemical properties of the SDA are shown in Table 1. From the Table, it can be observed that two distinct group, according to the dominant chemical compound exists.

\begin{tabular}{|l|r|r|r|r|r|r|r|r|r|r|}
\hline Researchers & $\mathbf{S i O}_{2}$ & $\mathbf{A l}_{2} \mathbf{O}_{3}$ & $\mathbf{F e}_{2} \mathbf{O}_{3}$ & $\mathbf{C a O}$ & $\mathbf{M g O}$ & $\mathbf{S O}_{3}$ & $\mathbf{N a}_{2} \mathbf{O}$ & $\mathbf{K}_{2} \mathbf{O}$ & $\mathbf{L O I}$ & $\mathbf{S A F}$ \\
\hline Abhishek and Kumbar [41] & $\mathbf{9 . 6 0}$ & $\mathbf{2 . 0 0}$ & $\mathbf{1 . 6 0}$ & $\mathbf{4 2 . 5 0}$ & $\mathbf{3 . 7}$ & $\mathbf{1 . 0 0}$ & $\mathbf{1 . 3 0}$ & $\mathbf{5 . 3 0}$ & & $\mathbf{1 3 . 2 0}$ \\
\hline Cheah et al. [42] & 2.70 & 1.30 & 1.30 & 61.0 & 8.70 & 2.80 & - & 12.0 & 18.0 & 5.30 \\
\hline Ogork and Ayuba [25] & 7.52 & 3.50 & 1.47 & 50.64 & 5.02 & 1.20 & 3.61 & 19.93 & 4.20 & $\mathbf{1 2 . 4 9}$ \\
\hline Naik et al. [36] & 8.10 & 7.50 & 3.00 & 25.30 & 4.50 & 12.50 & 3.30 & 2.70 & 32.80 & 18.60 \\
\hline Adamu et al. [43] & 46.90 & 1.34 & 1.21 & 21.60 & 1.20 & 0.22 & 2.03 & 1.00 & 24.50 & 49.90 \\
\hline Awolusi et al. [44] & 65.05 & 4.68 & 2.23 & 9.72 & 3.89 & 1.01 & 0.05 & 2.12 & 4.05 & 71.96 \\
\hline Raheem et al. [45] & 65.75 & 5.23 & 2.09 & 9.62 & 4.09 & 1.09 & 0.06 & 2.43 & 4.30 & $\mathbf{7 3 . 0 7}$ \\
\hline Chowdhury et al. [39] & 65.30 & 4.25 & 2.24 & 9.98 & 5.32 & - & 2.60 & 1.90 & 4.67 & 71.79 \\
\hline Kumar et al. [46] & 62.87 & 9.85 & 4.45 & 10.35 & 4.16 & - & 0.04 & 1.71 & 5.85 & 77.17 \\
\hline Elinwa and Mamuda [17] & 67.20 & 4.10 & 2.30 & 10.0 & 5.80 & 0.50 & 0.10 & 0.10 & 4.60 & 73.50 \\
\hline Ettu et al. [46] & $\mathrm{NA}$ & $\mathrm{NA}$ & $\mathrm{NA}$ & $\mathrm{NA}$ & $\mathrm{NA}$ & $\mathrm{NA}$ & $\mathrm{NA}$ & $\mathrm{NA}$ & $\mathrm{NA}$ & $>70$ \\
\hline Cheah and Ramli [32] & 28.00 & 4.00 & 2.50 & 39.0 & - & 1.00 & 1.0 & 7.0 & 7.2 & 34.6 \\
\hline Marthong [47] & 50.20 & 1.02 & 14.23 & 5.45 & 0.09 & 0.58 & 0.07 & 9.57 & 3.67 & 65.45 \\
\hline Tyagher et al. [48] & 67.95 & 4.29 & 2.15 & 9.47 & 5.84 & 0.56 & 0.06 & 0.11 & 9.57 & 74.39 \\
\hline Mageswari and Vidivelli [49] & 65.30 & 4.0 & 2.23 & 9.60 & 5.80 & - & - & 0.11 & 12.96 & 71.53 \\
\hline Abdullahi [31] & 31.80 & 28.0 & 2.64 & 10.50 & - & 0.45 & 6.5 & 10.4 & 27.00 & 62.10 \\
\hline Naik et al. [36] & & & & & & & & & & \\
\hline W1 & 32.40 & 17.10 & 9.80 & 3.50 & 0.70 & 2.20 & 0.90 & 1.10 & 31.60 & 59.30 \\
\hline W2 & 13.00 & 7.80 & 2.60 & 13.70 & 2.60 & 0.90 & 0.60 & 0.40 & 58.10 & 23.40 \\
\hline W3 & 50.70 & 8.20 & 2.10 & 19.60 & 6.50 & 0.10 & 2.10 & 2.80 & 6.70 & 61.00 \\
\hline W4 & 30.00 & 12.30 & 14.20 & 2.20 & 0.70 & 2.10 & 0.50 & 2.00 & 35.30 & 56.50 \\
\hline Udoeyo and Dashibil [50] & 78.90 & 0.89 & 0.85 & 0.58 & 0.96 & - & - & - & 8.4 & 80.64 \\
\hline
\end{tabular}

$* \mathrm{SAF}=\mathrm{SiO}_{2}+\mathrm{Al}_{2} \mathrm{O}_{3}+\mathrm{Fe}_{2} \mathrm{O}_{3}$

Table 1. Chemical Properties Saw Dust Ash

These are high calcium oxide group and high silicate oxides group, and that within each group, wider range of chemical composition exist. The sum of $\mathrm{SiO}_{2}+\mathrm{Al}_{2} \mathrm{O}_{3}+\mathrm{Fe}_{2} \mathrm{O}_{3}$ of the SDA in the majority of the silicate oxides group is between 50 and $70 \%$, and thus are in the same category with the Classes $\mathrm{C}$ and $\mathrm{F}$ fly ash [51] with high pozzolanic characteristics. The calcium oxide group with combined total of $\mathrm{SiO}_{2}+\mathrm{Al}_{2} \mathrm{O}_{3}+\mathrm{Fe}_{2} \mathrm{O}_{3}$ being less than $70 \%$ did not fall into this category. The fact that wood waste ash falls into two dominant group (calcium oxide and silicates oxides groups) and exhibits wider range of chemical composition as in Table 1 was also supported by the work of [52]. Some curios look at Table 1 however reveals a credible fear, that is, the high loss on ignition, which is a measure for the residual carbon content, recorded by all the researchers. The high loss on ignition was attributed to uncontrolled incineration [ 50 , $51,53,54]$. The American standard [51 limits loss on ignition to $6 \%$ (for class $\mathrm{C}$ and $\mathrm{F}$ fly ash 
when used in concrete), while BS 12 [55] limits LOI of Portland cement to 3\%. Majority of the SDA used by the researchers in the Table did not meet the specifications.

\subsection{Pozzolanic Properties of Concrete with SDA}

X-ray fluorescence (XRF) analysis results of wood waste ash samples by [56], confirmed the presence of essential chemical compounds governing pozzolanic reactivity namely $\mathrm{SiO}_{2}$, $\mathrm{Al}_{2} \mathrm{O}_{3}$ and $\mathrm{Fe}_{2} \mathrm{O}_{3}$ in significant amounts within the wood waste fly ash samples examined. They however observed a stronger pozzolanic activity in samples with higher $\mathrm{SiO}_{2}+\mathrm{Al}_{2} \mathrm{O}_{3}$ $+\mathrm{Fe}_{2} \mathrm{O}_{3}$ chemical compositions. The effectiveness of SDA as a pozzolan was the subject of investigation conducted by [57], using efficiency factor as per [58,59]. They discovered that after certain percentages in the concentration of $\mathrm{Al}_{2} \mathrm{O}_{3}, \mathrm{Fe}_{2} \mathrm{O}_{3}$ and $\mathrm{CaO}$ in the ash, even for high $\mathrm{SiO}_{2}$ content, high level of fineness, and low values of LOI, the derived efficiency factors drop below 1.0. They thus concluded that high $\mathrm{SiO}_{2}$ content in SDA, does not automatically implies an effective pozzolanic material with a high efficiency factor.

\subsection{Hydration of Paste with Wood Waste Ash}

Scanning Electron Microscopy (SEM) observation on the microstructure of CTL paste (0\% cement replacement with WWA) by [60] showed abundant calcium hydroxide plated crystals at $24 \mathrm{hr}$ evolving into perfect hexagonal shaped crystals at 5 days. This agrees with [61] and in accordance with [62] who stated that $\mathrm{Ca}(\mathrm{OH})_{2}$ liberated by the hydrolysis of the calcium silicates forms hexagonal plates often tens of micro-meters across.

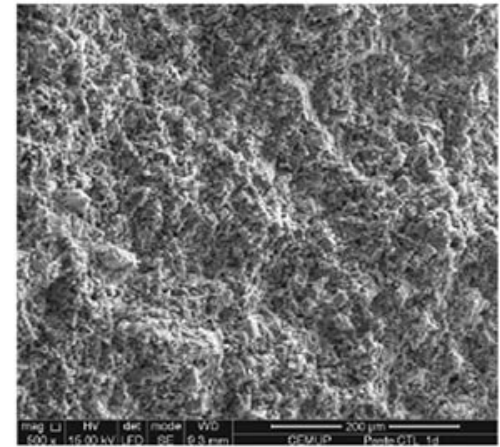

CTL, 24hours, 500 times enlarged

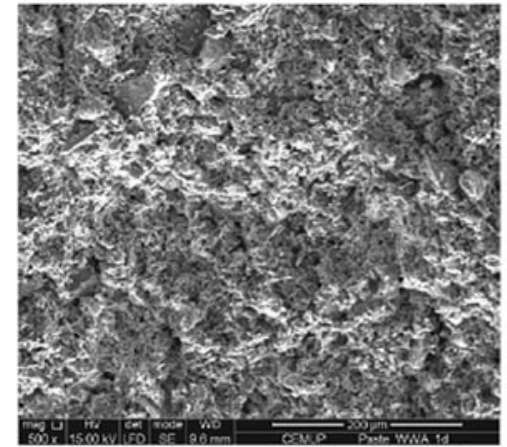

WWA 10, 24hours, 500 times enlarged

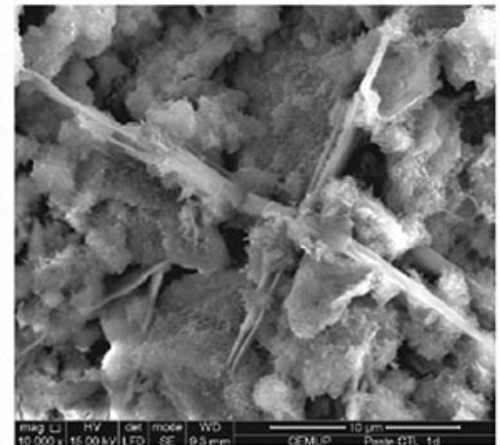

CTL, 24hours, 10000 times enlarged

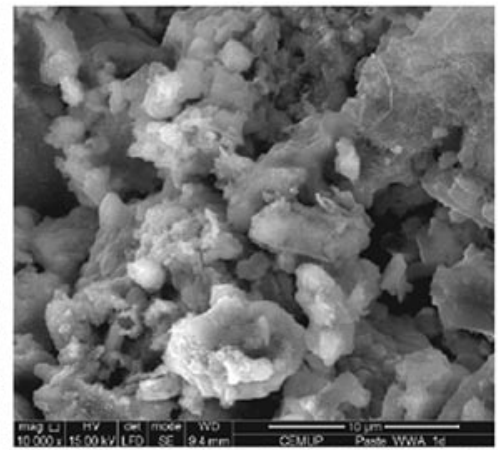

WWA 10, 24hours, 10000 times enlarged

Figure 2. Hydrated Cement Paste and Wood waste ash Paste at 24hr [60] 
No calcium hydroxide was identified in Wood waste ash (WWA) 10 paste at $24 \mathrm{hr}$. Some plates were detected in WWA 40 paste 5 days old but a much more reduced amount compared to the control samples than the 5 days old paste. Denser C-S-H was naturally found at 5 days old paste. Specimens with $40 \%$ wood waste ash (WWA), at 5-days old paste seems to present less ettringite compared to the control specimens paste the same age. This seems to confirm findings by [63] who affirmed that ettringite can be transformed into monosulphate in low $\mathrm{SO}_{3}$ fly ash cement.

\section{FRESH STATE BEHAVIOURS}

\subsection{Consistency of Mortar with SDA}

Knowledge of consistency performance of a material is important in the production of structural concrete as it gives indication on water requirement of the material. Findings from various investigations by researchers $[31,53,54]$ established that the inclusion of wood waste ash as a partial cement replacement material in blended cement resulted in a higher water requirement in order to achieve a standard level of cement paste consistency. Water demand for Ordinary Portland cement-saw dust ash (OPC-SDA) paste increases proportionately with the level of cement replacement by SDA expressed as a percentage of total binder's weight. The higher water demand of OPC-SDA paste relative to OPC is mainly due to a higher specific surface area of porous wood waste ash particles in comparison to OPC particles.

\subsection{Setting Times of Mortar with SDA}

Setting times - initial and final - are important in the production of structural concrete as they control the rate at which the concrete hardens, so as to commence strength development processes of hydration. Results from the works of many researchers [25, 33, 47, 50, 54] showed that both the initial and final setting times increased with increase in percent replacement of cement with SDA. The typical pattern is as shown in Figure 3.

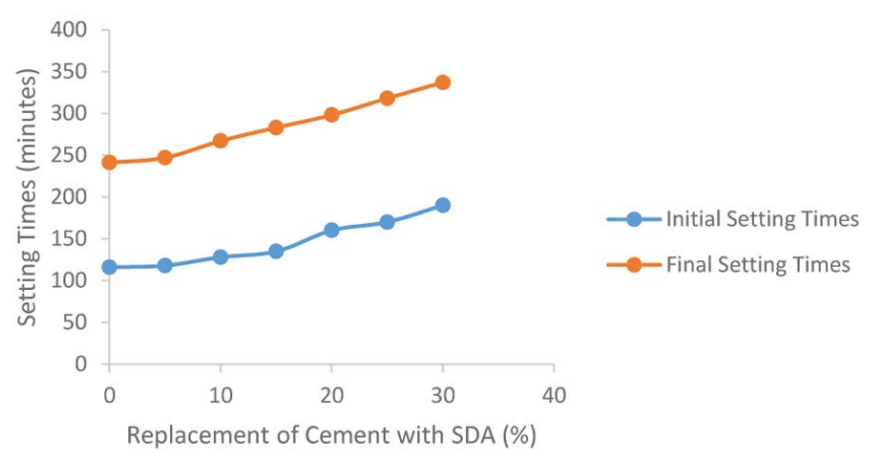

Figure 3. Effect of SDA on Setting Times of OPC-SDA Paste [54]

The seeming retarding effects of SDA on OPC-SDA paste was attributed by [33] to highest contents of sulphates and heavy metals (particularly, $\mathrm{Zn}, \mathrm{Pb}$ and $\mathrm{Cu}$ ) in SDA. Although, SDA will result in delayed and lower hydration, its retarding effects could however proof useful when concrete will have to be transported over a long distance, without losing its workability. The slow hydration of OPC-SDA could also be advantageous in mass concreting as it helps to offset the stress induced by temperature differential 


\subsection{Soundness}

According to [62], it is essential that cement paste, once it has set, does not undergo a large change in volume that could lead to disruption of the hardened cement paste, thereby hastening structural deterioration in concrete. There are evidences from the results of investigations carried out by $[50,53,54]$ that soundness values obtained by the replacement of cement with wood ash were within the maximum allowed by international standard. These researchers obtained average soundness values of about 1.45 , at the replacement level of up to $30 \%$. This value is well below the maximum allowable soundness value of $10 \mathrm{~mm}$ specified by BS EN [64]. This is an indication that incorporation of wood ash up to $30 \%$ replacement of cement will not result in unsound concrete.

\subsection{Workability of Concrete with SDA}

Investigation by researchers to assess workability of concrete specimens with SDA through slump and compacting factor tests showed that both the values obtained for slump and compacting factor decreased with increase in cement replacement with SDA [23, 25, 47]. A typical plot using the data from the works of $[37,53]$ is shown in Figure 4.

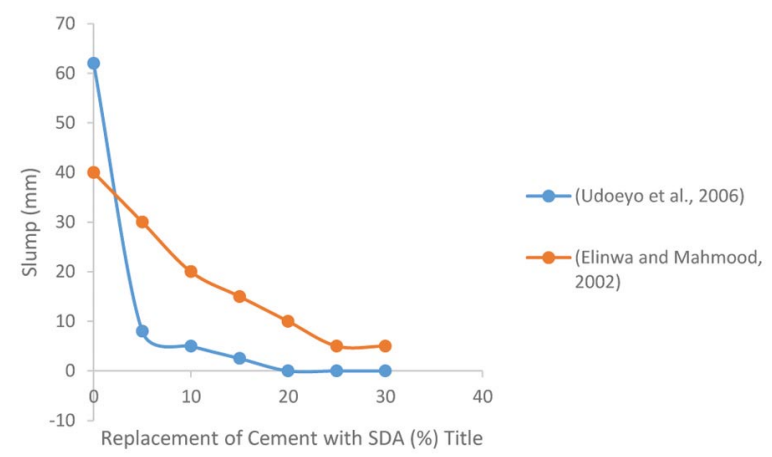

Figure 4. Slump characteristic of concrete specimens with SDA [37, 53]

In order words, the material becomes less workable, turning into harsh mixes with increased content of SDA, and thus require higher water content to main its workability. Subbaramaiah [26] concluded that the higher water content to attain a reasonable workability may be due to the relatively high carbon content in wood waste ash. Appropriate dosage of super plasticiser could be used with SDA to maintain required workability $[62,65,66]$.

\section{HARDENED STATE PROPERTIES}

\subsection{Density}

Knowledge of the density of concrete is important for correct and efficient application. For structural considerations, concrete is classified according to density into three, namely, light weight concrete, normal weight concrete and heavy weight concrete with densities $300-1,920$ $\mathrm{kg} / \mathrm{m}^{3}$, of $2,240-2,480 \mathrm{~kg} / \mathrm{m}^{3}$, and greater than $2,500 \mathrm{~kg} / \mathrm{m}^{3}$ respectively [67]. The results of various investigations conducted by researchers $[24,32,68]$ showed that the densities of specimens containing SDA as partial replacement of cement up to $40 \%$ to be within the range of 2220 and $2316 \mathrm{~kg} / \mathrm{m}^{3}$. 
These findings established that usage of SDA for concrete production resulted in densities in the normal weight categories, and thus can be used for conventional normal weight applications.

\subsection{Compressive Strength Properties}

The compressive strength of concrete is important because it governs the design of structural concrete being the property specified by standards and codes for compliance. All other structural properties such as flexural strength, splitting tensile strength and modulus of elasticity directly depend on the compressive strength of the concrete. There seems to be consensus among researchers that the compressive strength development of concrete containing SDA, though increased with curing ages, nonetheless deceased in relation to the control with increase in the percent replacement of cement with SDA [23, 37, 42, 47]. The general trend is shown in Figure 5. Udoeyo et al. [37] thought that the trend observed is most probably due to the mechanism that wood waste ash particles act more like filler material within the cement paste matrix than as binder material. Thus, increasing ash content as replacement of cement resulted in an increased surface area of filler material to be bonded by decreasing the amount of cement which caused a decline in strength.

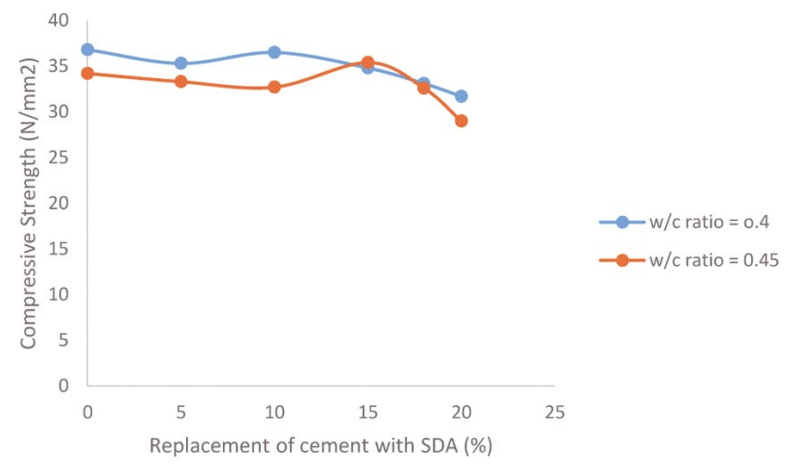

Figure 5. Typical Strength Development in Concrete with SDA [42]

Notwistanding the deacrese in compressive strength in relation to the control, numerical values of compressive strength obtained from cube tests by researchers suggested that SDA and wood ash (WA) can be incorpotrated into the concrete mixes to develop the required strength specified by various international standards. British standards [69] specification for different concrete class is as shown in (Table 2).

\begin{tabular}{|c|c|l|}
\hline Grade & Characteristic Strength $\mathbf{( N / \mathbf { m m } ^ { 2 } )}$ & \multicolumn{1}{|c|}{ Concrete Class } \\
\hline 7 & 7 & Plain concrete \\
10 & 10 & Reinforced concrete with lightweight aggregate \\
\hline 15 & 15 & Reinforced concrete with dense aggregate \\
\hline 20 & 20 & \\
25 & 25 & Concrete with post tensioned tendons \\
\hline 30 & 30 & \\
\hline 40 & 40 & Concrete with pre-tensioned tendons \\
50 & 50 & \\
60 & 60 & \\
\hline
\end{tabular}

Table 2. Characteristic Compressive Strength for Structural Concrete [69] 
Analysis of the works of researchers (Table 3) demostrated that concrete incorporating wood ash, with the correct water-cement ratio can designed to achieve the desired 28-day compressive strength required in rienforced concrete. The American standards $[72,73]$ set a cylindrical compressive $\left(f_{c}\right)$ strength of $17 \mathrm{MPa}$ (equivalent to 20MPa cube strength) as the benchmark for structural concrete.

\begin{tabular}{|l|c|c|c|c|c|}
\hline \multicolumn{1}{|c|}{ Authors } & Mix & w/c Ratio & $\begin{array}{c}\text { Max. 28-day } \\
f \mathrm{c}\left(\mathrm{N} / \mathrm{mm}^{2}\right)\end{array}$ & Dosage (\%) & $\begin{array}{c}\text { Group } \\
\text { (Table 1) }\end{array}$ \\
\hline Chowdhury et al. [39] & NA & $\begin{array}{l}0.40 \\
0.45\end{array}$ & $\begin{array}{c}31.7-35.3 \\
29.0-33.3\end{array}$ & $\begin{array}{c}5-20 \\
5-20\end{array}$ & $\mathrm{CaO}$ \\
\hline Marthong [70] & NA & NA & 32.50 & Up to 10 & $\mathrm{SiO}_{2}$ \\
\hline Ogork and Ayuba [25] & $1: 2: 4$ & 0.55 & 20 & Up to 10 & $\mathrm{CaO}$ \\
\hline Raheem et al [23] & $1: 2: 4$ & 0.60 & 15 & Up to 10 & $\mathrm{SiO}_{2}$ \\
\hline Subbaramaiah [26] & $1: 1.84: 2.89$ & 0.50 & $24-39.74$ & Up to 40 & $\mathrm{NA}$ \\
\hline Ettu et al. [71] & $1: 2: 4$ & 0.60 & 20.90 & Up to 10 & $\mathrm{SiO}_{2}$ \\
\hline Abhishek and Kumbar [41] & $1: 1.61: 2.78$ & 0.45 & $25-36$ & Up to 15 & $\mathrm{CaO}^{2}$ \\
\hline Adamu et al [42] & $1: 2: 4$ & 0.55 & $22-28$ & Up to 15 & $\mathrm{SiO}_{2}$ \\
\hline
\end{tabular}

Table 3. Numerical Values of 28-day Compressive Strength of Specimens with SDA

It is obvious from Table 3, with the exception of [23] which can be improved with lower water-cement ratio, that most of the researchers achieved the cylindrical strength of $17 \mathrm{MPa}$ (equivalent of $20 \mathrm{MPa}$ cube strength) benchmark for structural concrete set by $[72,73]$. However, at the curing ages of 90 days, the results of [16] showed improved compressive strength over the control samples at replacement levels up to $30 \%$. The latter days' strength improvement is characteristics of pozzolans. The above observations are independent of the groupings of the SDA, that is, whether it is calcium group or silicates group (Table 1). The observations that a material could be included in the concrete mix to produce the required strength without necessarily being pozzolanic as per [51] had been established by the works of [74].

\subsection{Tensile Performance of Concrete with SDA}

The strength of concrete in tension is of interest in the design of some structures, for examples, in the design of highway and airfield slabs, shear strength, and resistance to cracking [62]. Tensile stresses can cause cracks that are sufficient to put into dangers durability characteristics of concrete. It is usually assessed through splitting tests (splitting tensile strength) and modulus of rupture test (flexural tensile strength).

\subsubsection{Splitting Tensile Strength of Concrete with SDA}

The general pattern of the effect of SDA on the splitting tensile strength of concrete is reduction with increasing content of SDA, especially at early ages up to 28-day curing [35, 50]. This is shown in Figure 6. 


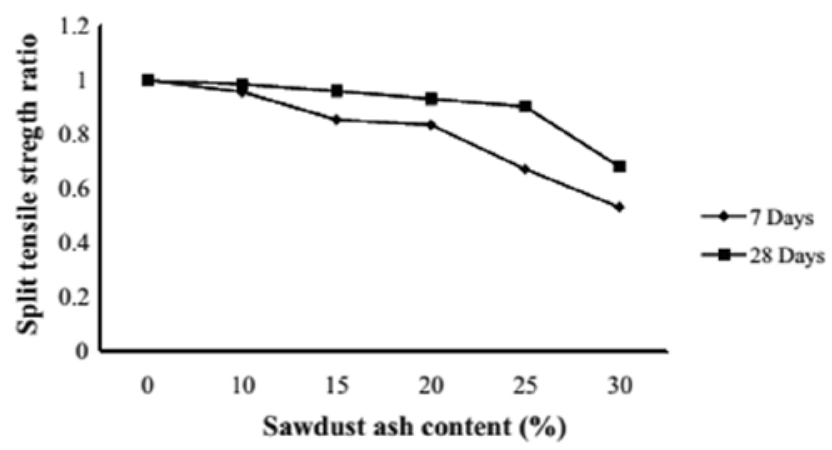

Figure 6. Effect of SDA on Splitting Tensile Strength of Concrete [50]

There are indications however that the splitting tensile strength of concrete increases at replacement levels up to $30 \%$ at 90 days and above curing age, but at a decreasing rate [16]. Investigations by [35] further established that for ages of concrete beyond 28 days up to 365 days, the concrete mix with wood ash content of $8 \%$ total binder weight exhibited the best split tensile strength development behaviour with a magnitude of split tensile strength consistently exceeded those of other test mixes.

\subsubsection{Flexural Tensile Strength of Concrete with SDA}

Like the splitting tensile strength, the flexural strength of concrete specimens with SDA deceased with increase in the content of SDA up to 28 days of curing. The trend was established by the works of $[35,37,41,56]$. However, curing beyond 28 days resulted in a reversed trend. Naik et al. [35] showed that the developed flexural strength at 5, 8, and $12 \%$ cement replacement with SDA were higher than the control specimens at 365 days with the mix which had 5\% SDA exhibiting the highest flexural strength

\subsection{Relation between Compressive and Tensile Strengths of Concrete with SDA}

Developing a relationship between the compressive strength and the tensile strength (flexural and splitting) is very important in the design of structural concrete. However, assessing the tensile strength either from the modulus of rupture or splitting test is difficult to obtain for the purpose of control and compliance [75]. Therefore, compressive strength, which is easily measured, is used as an indirect means to assess the flexural strength (obtained as modulus of rupture) and the splitting tensile strengths of concrete. None of the researchers who have worked on SDA so far has tried to obtain this relationship. However, the data from some of them have been used to compute these ratios, which are presented in Table 4.

\begin{tabular}{|c|c|c|c|c|}
\hline \% SDA in Mix & Abhishek and Kumbar [41] & Subbaramaiah, [26] & Chowdhury et al. [39] & Ghorpade [16] \\
\hline 0 & - & $0.1(10 \%)$ & $0.1(10 \%)$ & $0.1(10 \%)$ \\
\hline 5 & $0.08(8 \%)$ & - & $0.1(10 \%)$ & \\
\hline 10 & $0.08(8 \%)$ & $0.1(10 \%)$ & $0.1(10 \%)$ & $0.1(10 \%)$ \\
\hline 15 & $0.08(8 \%)$ & - & $0.09(10 \%)$ & \\
\hline 20 & $0.08(8 \%)$ & $0.09(9 \%)$ & $0.09(10 \%)$ & $0.1(10 \%)$ \\
\hline 25 & - & - & - & - \\
\hline 30 & - & $0.1(10 \%)$ & - & - \\
\hline 35 & - & - & - & - \\
\hline 40 & - & $0.09(9 \%)$ & - & - \\
\hline
\end{tabular}

Table 4. Ratio of Splitting Tensile Strength to Compressive Strength of Concrete with SDA at 28-day curing 
From Table 4, it can be seen that the splitting tensile strength is between $9-10 \%$ of the compressive strength at the replacement levels considered. Although many relations have been developed, expressing relationship between splitting tensile strength and compressive strength [76 - 79], it is usual in reinforced concrete design and constructional practice to take the tensile strength as about $10 \%$ of the compression strength [80]. The results presented in Table 4 of concrete containing SDA up to $40 \%$ of cement replacement, though scanty, largely agreed with this.

\subsection{Stiffness of Concrete with SDA}

Stiffness is a measure of resistance to bending of a material, and it is assessed through the load-deflection curve of loaded beam specimens. From the results of the investigation carried out by [26], concrete beam specimens containing up to $10 \%$ replacement of cement with SDA showed improved stiffness resistance when compared to the control (Figure 7). Further increase in replacement levels decreased the stiffness of the concrete marginally.

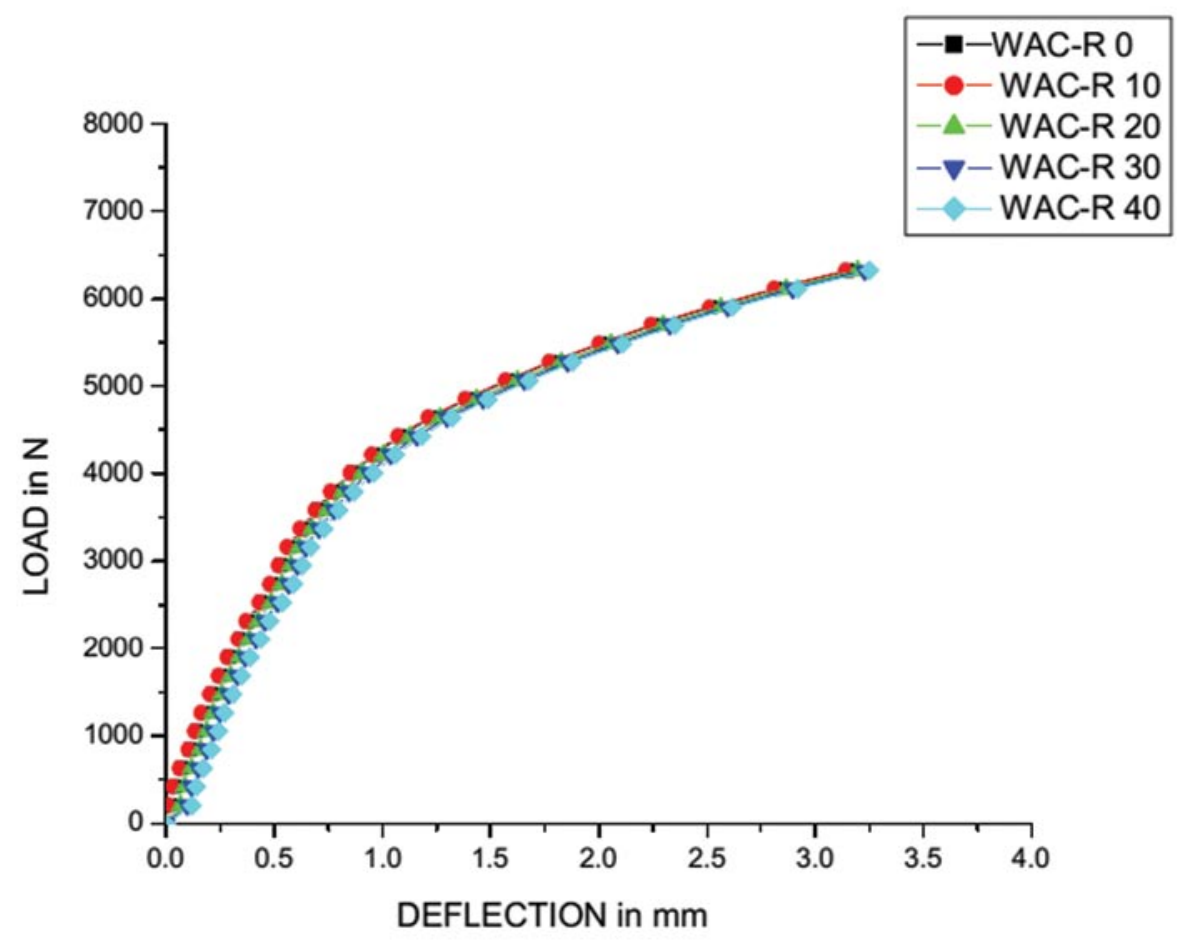

Figure 7. Load-deflection curve of concrete with SDA [26]

\section{DURABILITY AND FUNCTIONAL PROPERTIES}

It is essential that every concrete structure should continue to perform its intended functions, that is, maintain its required strength and serviceability, during the specified or traditionally expected service life, without reaching a state when it becomes unserviceable [62, 69]. To be durable, concrete must be able to withstand the processes of deterioration to which it can be expected to be exposed in the domiciled environment. 
Until recently, developments in cement and concrete technology have concentrated on achieving higher and higher strengths, assuming that 'strong concrete is durable concrete [62]. It is now known that, for many conditions of exposure of concrete structures, both strength and durability have to be considered explicitly at the design stage, especially in the Limit State method (LSM) of design where a structure must be designed in such a way that a state of unserviceability is avoided. The aspects of durability of concrete with SDA are now discussed.

\subsection{Water Absorption}

Many structural materials used in the construction industry are porous. The ingress of moisture and the transport properties of these materials have become the underlying source for many engineering problems such as corrosion of reinforcing embedded steel, and damage due to freeze-thaw cycling or wetting and drying cycles [81]. Concrete is a porous material that interacts with the surrounding environment. According to [62], a good concrete should have water absorption of less than $10 \%$ to be durable. Figure 8 is the results of the investigation conducted by [37].

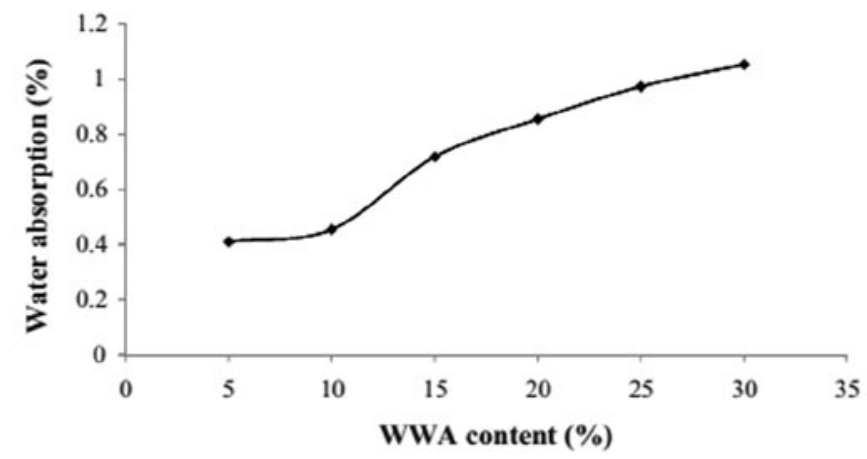

Figure 8. Effect of Wood waste ash on the water absorption of Concrete [37]

It can be observed that up to $30 \%$ replacement levels, the water absorption is about $10 \%$, thus within this region, durable structural concrete will be produced as per [62]. Later works carried out by $[32,41]$ were in agreement with this. Marthong [47] further showed that water absorption of concrete with SDA decreased with age. He attributed this behaviour to the fact that hydration products gel gradually fills the original water filled spaces, this makes it impervious to water intrusion. Also, from Figure 7, it can be observed that water absorption increased with percent replacement of cement with SDA. This agrees with the findings of Siddique [82].

\subsection{Shrinkage}

Shrinkage of concrete is cause by the settlement of solids and the loss of free water from the fresh concrete (plastic shrinkage), or the chemical combination of cement with water (autogenous shrinkage), or by the drying out of the concrete (drying shrinkage) [80]. When this settlement is restrained, shrinkage will produce tensile stresses within the concrete, resulting in cracking. A cracked concrete exposes the concrete, especially reinforcement in the reinforced concrete, to all manner attack and lead to deterioration. At cement replacement levels with SDA of 5,8 , and $12 \%$, Naik et al. [35] found out the drying shrinkage at 232 curing days were $-0.014,-0.051-0.044$ as against -0.052 recorded for the control specimens. Autogenous and drying shrinkage investigations conducted on mortar specimens by [32] showed that up to 
$15 \%$ cement replacement with SDA containing high carbon content brought about improved shrinkage properties compared to the control specimens. This result showed improved performance of concrete specimens containing up to $12 \%$ SDA against shrinkage. Marthong [47] attributed this to reduction in water demand with inclusion of SDA (which produces harsh concrete, since shrinkage involves loss of water) and subsequent production of finer paste structure that is attendant to hydration process, which restrict the loss of pore water within the paste, as the reasons for the shrinkage behaviour of specimens with SDA.

\subsection{Alkali-Silicate Reaction (ASR)}

The reactions between the alkalis and reactive silica and some carbonates in aggregate, usually disruptive in nature, manifest itself in the form of cracking which can facilitate the ingress of harmful agents. The crack width can range from $0.1 \mathrm{~mm}$ to as much as 10 $\mathrm{mm}$ in extreme cases. The alkali-silica reaction adversely affects the appearance and serviceability of a structure [62], a condition to design against as per the limit state requirement of [69]. Ramos et al [60], guided by [83], investigated the capacity of mortar specimens with wood ash to protect against ASR. They were of the opinion that wood waste ash was effective in reducing ASR expansion and increasing WWA content led to lower expansion. Replacing cement with $20 \%$ WWA led to a low risk binder/aggregate combination in relation to ASR, with expansion below the $0.1 \%$ target. Similar results were also obtained by $[60,84]$. Wang and Baxter [84] used sawdust-coal co-fired fly ash in their own investigation.

\subsection{Carbonation}

The behaviour of concrete in the presence of the $\mathrm{CO}_{2}$ and moisture caused reaction with the hydrated cement to produce a phenomenon called carbonation [62]. Carbonation of $\mathrm{Ca}(\mathrm{OH})_{2}$ causes the lowering of $\mathrm{pH}$ of the pore water from about 13.5 to a value lower than 9.0. In reinforced concrete, the high $\mathrm{pH}$ forms a protective barrier - known as passivation - against initiation of corrosion. At lower $\mathrm{pH}$, the passivation is destroyed and corrosive reactions results. Thus, it is important to know the depth of carbonation and specifically whether the carbonation front has reached the surface of the embedded steel or not. The results of investigation conducted by [32] on high carbon SDA show that the depth of carbonation of specimens at 5, 10, 15, 20, 25\% cement replacement with SDA was found to be lower than the control only at 5\% replacement level. The depth of carbonation at the replacement levels of up to $20 \%$ investigated by $[60,85]$ were found to be higher than the control. This is an indication of poor carbonation performance of specimens with SDA.

\subsection{Chloride Resistance}

Chloride attack is distinct in that the primary action is the corrosion of steel reinforcement. It is in consequence of this corrosion - brought about by the transport of chloride ions through the concrete in the cover to the reinforcement - that the surrounding concrete is damaged [62]. Corrosion of reinforcement is one of the major causes of deterioration of reinforced concrete structures in many locations. Wang et al. [84] conducted investigation to evaluate the potential of SDA concrete specimens to resist chloride ion penetration, in accordance to the rapid chloride permeability test as per ASTM C1202-91 [87]. Their results showed chloride penetration resistance performance comparable to the control samples up to $25 \%$ replacement, provided air entrainment is used. Their results further revealed that specimens without air entrainment were vulnerable to chloride ingress. The work of [88] agreed with these observations. 


\subsection{Sulphate Resistance}

Solid salts do not attack concrete but, when present in solution, they can react with hydrated cement paste. Particularly common are sulphates of sodium, potassium, magnesium, and calcium which occur in soil or in groundwater or disused industrial sites. The significance of this lies in the fact that those other sulphates react with the various products of hydration of cement and not only with $\mathrm{Ca}(\mathrm{OH})_{2}$ [62]. For example, Calcium sulphate can attack calcium aluminate hydrate, forming calcium sulfoaluminate, known as ettringite, which in mature concrete tends to be disruptive and harmful. Also, magnesium sulphate can attack calcium silicate hydrates as well as $\mathrm{Ca}(\mathrm{OH})_{2}$ and calcium aluminate hydrate causing the destruction of the strength forming C-S-H gel in concrete. The works of [41] showed that concrete with sawdust ash as partial replacement of cement loses its resistance to sulphate with increasing content of SDA. Implication of using SDA in concrete is that it can expose the strength dependent C-S-H gel of the matrix to sulphate attack, and this can lead to reduction in the strength of concrete, which may cause the structural failure.

\subsection{Resistance against acid attack}

Structural concrete containing Portland cement, being highly alkaline, is not resistant to attack by strong acids or compounds which may convert to acids [62]. Also using in appropriate mix design or when concrete is not properly compacted can expose the concrete to chemical attack. Chemical attack of concrete occurs by way of decomposition of the products of hydration and formation of new compounds which, if soluble, may be leached out and, if not soluble, may be disruptive in situ. The attacking compounds must be in solution. The most vulnerable cement hydrate is $\mathrm{Ca}(\mathrm{OH}) 2$, but $\mathrm{C}-\mathrm{SH}$ can also be attacked. Calcareous aggregates are also vulnerable. ACI [89] gives the lists of substances which attack concrete to varying degrees. Elinwa and Ejeh [54] studied the effect of nitric acids and sulphuric acid on mortar specimens containing SDA. There results showed that specimens containing SDA up to $10 \%$ offered better resistance to deterioration by nitric acids than Portland - cement mortar. At the same level of replacement, specimens were not able to prevent attacks by sulphuric acid. They then conclude that concrete specimens may not be able to perform functionally in a sulphuric acid environment.

\subsection{Resistance of wood waste ash concrete against freeze-thaw action}

In the cold climates, a major cause of lack of durability of concrete is frost action [62, 65]. In such environment, exposure of mature concrete to alternating freezing and thawing cannot be avoided, leading to progressive damage of concrete structures. Effects of wood ash at the replacement levels of $5 \%, 8 \%, 12 \%$ of cement, on freezing and thawing resistance of concrete was investigated by [35] by evaluating the changes in relative dynamic modulus, pulse velocity and change in length. The result showed no effect of the freeze-thaw cycle (300 cycles) on both the relative dynamic modulus and pulse velocity of the concrete in relation to the control samples. Also, in terms of length variation under the freeze thaw action, for the control concrete mix percent change in length recorded was $0 \%$ (at 32 cycles) $/-0.00556 \%$ (at 300 cycles). For the concrete mix with wood ash content of 5, 8 and $12 \%$, percentage length changes after 32 and 360 freeze thaw cycles were recorded as $-0.003273 \% / 0.01113 \%, 0.002942 \% / 0.00903 \%$ and $-0.000417 \% / 0.01156 \%$ respectively. This was an indication that concrete containing SDA up to $12 \%$ perform just as the control vis-à-vis resistance to frost action. 


\section{SAW DUST WASTE AS PARTIAL REPLACEMENT OF FINE AGGREGATES FOR STRUCTURAL CONCRETE PRODUCTION}

Attempts are being made by researchers and scholars - though relatively few - to evaluate the performance of concrete containing wood waste as fine aggregate, in the production of structural concrete. Their findings are discussed below.

\subsection{Usage as Fine Aggregate in Concrete}

\subsubsection{Production and Properties of Saw Dust (Fine Aggregate) aggregate}

Sawdust is generated from the mechanical processing of raw wood, which can be in the form of cutting, grinding, drilling, sanding, or pulverisation with saw of other tools. Sieve to the fineness of the used sand $[90,91]$. In this form, without pre-treatment, the following properties were extracted from the works of $[45,91-96]$ : moisture content $19.80 \%$, specific gravity 0.35 - 0.37 , bulk density $614-739.92 \mathrm{~kg} / \mathrm{m} 3$, absorption $1.4-2.0$, and fineness modulus 3.3 . It is glaring from these results that the sawdust is lighter than the fine aggregates which specific gravities of between $2.60-3.00[62,65]$

\subsection{Fresh State Properties}

\subsubsection{Workability}

Oyedepo et al [97] observed that the workability decreased as the percentage sawdust replacement of sand in the mix increases up to 50\%. Further increase to $100 \%$ replacement of sand with sawdust brought about increase in slump values. For example, slum values of $40 \mathrm{~mm}, 9 \mathrm{~mm}$ and $5 \mathrm{~mm}$ respectively was obtained for workability at $0 \%, 25 \%$ and $50 \%$ addition of sawdust as partial replacement for sand, but at $75 \%$ and $100 \%$ replacement of sand with sawdust, the workability of the cement mix increases to $6 \mathrm{~mm}$ and $15 \mathrm{~mm}$. Though they attributed this behaviour to the relatively higher water-cement ratio adopted for the work, it is obvious that more work need to be done to confirm this behaviour.

\subsection{Hardened State Properties}

\subsubsection{Density}

Density is an important structural property of concrete that must be correctly evaluated for its efficient application. From the results of the investigation conducted by [94], densities of concrete samples deceased as the percentage of replacement of fine aggregate with dust increased (from $0-100 \%$ ). However, considering the numerical values at 28 -day curing, the range of densities was $2100-2600 \mathrm{~kg} / \mathrm{m}^{3}$ for all the replacement values. From the works of [94], the range of densities were $1913-2331 \mathrm{~kg} / \mathrm{m}^{3}$. Also using the data obtained by [22], density of $1956 \mathrm{~kg} / \mathrm{m}^{3}$ was obtained at 28 days. This put the category of concrete produced from the replacement of fine aggregate with sawdust in the normal weight concrete category (Section 4.1). These results seemed anomalous, when viewed against the fact that all weightbased properties of sawdust, as documented in Section 2.1 are lower than that of fine aggregate that it replaced. One would have expected that it would develop densities in the light weight category range. More investigations are needed to establish this conclusively. 


\subsubsection{Compressive Strength}

The compressive strength of concrete with saw dust as partial replacement of fine aggregate decrease with increase in the level of replacement. However, considering the 28-day strength, which is needed for design and filed compliance purposes, the work of [98] showed that at 0 , $15,20,25$, and $30 \%$ replacement of fine aggregate with sawdust, the compressive strengths were $30.37,30.08,30.08,30.08$ and $29.48 \mathrm{~N} / \mathrm{mm}^{2}$ respectively. In the investigation of [92], the compressive strengths for 0 and $25 \%$ replacement were 21.60 and $15.90 \mathrm{~N} / \mathrm{mm}^{2}$. The results of the works of [95] are in agreement with these. Thus, these numerical results established that, with appropriate mix design, wood ash can be incorporated into the concrete mix to produce compressive strength that meet code requirement as discussed in section 2.3.2.

\subsubsection{Tensile Strength}

The results of flexural tensile strengths of concrete containing saw dust as partial replacement of fine aggregate seems to be conflicting. Olutoge [92] obtained results in which the flexural tensile strength decreased with increase in the content saw dust. The results for 28-day at $0,25,50,75$ and $100 \%$ replacement levels were $2.24,1.67,1.12,0.81$, and 0.55 . Albert et al [98] showed contrary results. At $0,15,20,25$ and $30 \%$ replacement levels, the flexural tensile strengths were found to be $4.38,4.38,4.44,4.44$, and 4.5 respectively. These results indicated improvement over control specimens at all levels of replacement considered. Albert et al. [98] thinks that the seeming improvement in the flexural properties of concrete with sawdust as partial replacement of fine aggregate is the fact that the saw dust used has the fibre in it, which served as a kind of reinforcement in the beam specimens.

\section{WOOD AGGREGATES AS PARTIAL REPLACEMENT OF COARSE AGGREGATES FOR STRUCTURAL CONCRETE PRODUCTION.}

\subsection{Production and Properties of Wood Concrete}

Wood aggregate was obtained by shredding wood wastes from furniture industries, construction industries and other wood work industries (Figure 9).

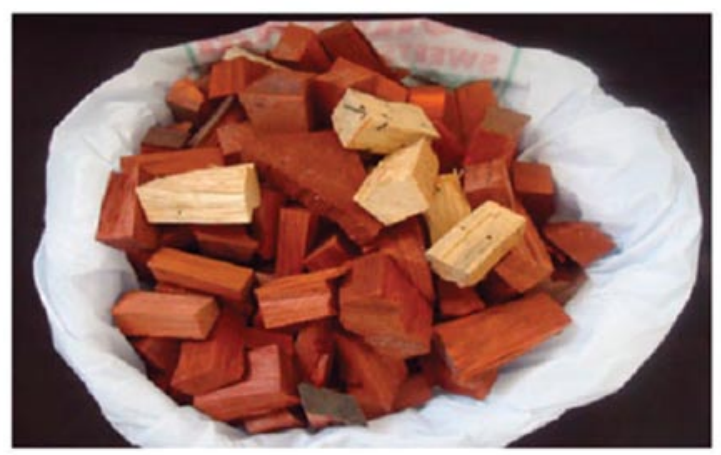

Figure 9. Wood Aggregate [99]

Some of the physical properties of wood aggregate, as found out by [99], include specific gravity of 2.4 , water absorption of $2.5 \%$ and fineness modulus of 6.9 . 


\subsection{Fresh State Properties of Concrete with Wood Aggregate \\ 7.2.1 Workability of Concrete with Wood Aggregate (WA)}

From the works of [99], the pattern of slump values in relation to increase in the percentage of coarse aggregate with WA is shown in Figure 10. It can be seen that slump value increased with percentage replacement of coarse aggregate by wood aggregate increased. This may be attributed to progressive loss in internal cohesion between the matrix as the content of wood aggregate in the mix is increased.

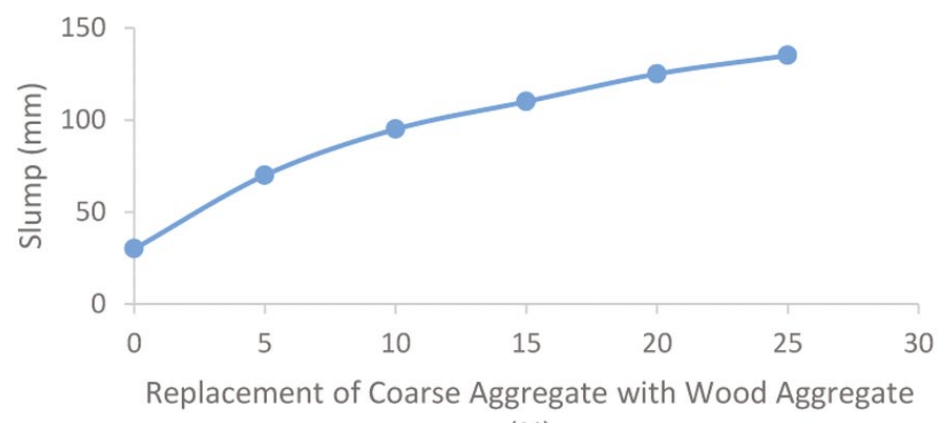

(\%)

Figure 10. Effect of WA on Workability of Concrete [99]

\subsection{Hardened State Properties of Concrete with Wood Aggregate}

From the results of the investigation conducted by [99], compressive strengths of concrete specimens decreased with increase in the percent replacement of coarse aggregate with WA. At $0,15,20$ and $25 \%$ percent replacement, the compressive strength was: $31.40,32.36,26$, 25 , and $22.60 \mathrm{~N} / \mathrm{mm}^{2}$ respectively. At $15 \%$ replacement, the compressive strength was higher than the control. The results of the work of [97] revealed that up to $25 \%$ replacement level, the compressive strength was the same as the control specimens. Although the compressive strength reduced in relation to the control at other replacement levels, the numerical value of the compressive strengths still meets the strength requirements as codes governing design of reinforced concrete (as discussed in Section 2.3.2). Both the splitting and flexural tensile strengths, as obtained from the work of [99], followed the pattern of the compressive strength. Samples at $15 \%$ replacement developed higher tensile strength than the control specimens, at other levels of replacement, reduction in the tensile strength was recorded.

\subsection{Durability Properties of Concrete with Wood Aggregate}

Thandavamoorthy [99] investigated some durability parameters, namely, acid and alkaline imperviousness, water absorption characteristics and fire resistance ability of concrete with wood aggregate. The results of acid test showed that the percentage loss in weight of control concrete was .66\% at 60 days and $.79 \%$ at 90 days, and the weight loss increased with the increase in percentage replacement with wood aggregate. He thus concluded that concrete with wood aggregate is susceptible to degradation under acid attack. He further observed that, at $15 \%$ replacement of coarse aggregate with wood aggregate, the concrete specimens were able to contain alkaline attack. Finally, he observed that no degradation due to fire took place, at 15 percent replacement with wood aggregate, excepting change in colour. 


\section{PROSPECTS OF USING WOOD WASTE FOR STRUCTURAL CONCRETE}

Structural concrete can be understood to mean a concrete that can develop sufficient strength to perform load-carrying functions, in accordance to relevant governing codes and standards. From this review, with respect to Table 2, it is obvious that concrete incorporating wood waste has the potential to be used for structural concrete. With right mix design and adoption of appropriate water-cement ratio, whether the partial replacement is for ash, or for coarse aggregate, or fine aggregate; a concrete with the strength specified in Table 2 can be obtained. The concrete elements in reinforced concrete required strengths of $15 \mathrm{~N} / \mathrm{mm}^{2}$ and above (Table 2). The numerical values of strengths presented above showed that these values can be easily achieved with proper mix design for substitution of between $15 \%$ and $20 \%$ of the various wood waste. It also ought to be stated that the use of SDA can also be used for soil improvement for construction purposes. For example, Butt et al. [100] obtained a satisfactory geotechnical properties and performance of clayey soil when SDA is used as stabilizing agent in conjunction with lime. Concrete with saw dust ash was also found to maintain its integrity at elevated temperatures up to $600^{\circ} \mathrm{C}$. (101)

\section{CONCLUSIONS AND RECOMMENDATIONS}

A comprehensive review has been made on the potential use of wood waste in concrete production in the built environment. The followings are the conclusions.

\subsection{Conclusions}

- Sawdust Ash is produced from the incineration of wood and biomass wastes, and thequality and quantity are governed by incarnation temperatures and techniques, as well as the source of timber.

- On the basis of the dominant chemical compound, saw dust ash chemical composition falls into two dominant, that is calcium oxide and silicate oxide groups, and within each of these groups, wider variation exists.

- In order to obtain a material with loss on ignition within the limits set by Codes, uncontrolled incineration should be avoided for the production of SDA for structural concrete.

- Increased dosage of SDA in the concrete mix resulted in reduced workability leading to harsh mix

- Inclusion of SDA increased initial and final setting times, and this increase with increasing percentage of SDA in the mix. It can be inferred that SDA behaves like a retarder

- With appropriate mix design, wood waste, either in the form of saw dust ash, or wood aggregate, or saw dust; can be incorporated into the concrete mix to develop structural concrete that satisfies codes requirements, provided the replacement is not above $20 \%$.

- Concrete incorporating SDA has good durability properties with the exception to vulnerability to carbonation and sulphate attack

- Wood aggregate and saw dust can be used, respectively for coarse aggregate and fine aggregate in concrete production, with appropriate concrete mix design. 


\subsection{Recommendations}

From the above review, the potentials for wood waste to be used as structural concrete constituent for the development of sustainable built environment is not in doubt. However, more works need to be done, either to confirm some observed behaviour, or extend to areas that are not yet covered. For example, some behaviour of concrete containing wood waste, that need to be understood, so as to capture its complete structural response, that are yet to be touched include: bending behaviour and associated properties like cracking and stiffness, shear behaviour, development of strength relations, and bond characteristics. These are thus recommended for further investigations.

\section{Funding}

The authors received no funding for this research.

\section{REFERENCES}

[1] ICE. (1975) The Institution of Civil Engineers - Royal Charter, By-Laws, Regulations \& Rule 1975; https://www.ice.org.uk/ICEDevelopmentWebPortal/media/Documents/Royal-Charter-By-laws-Regulationsand-Rules-2015.pdf (assessed 19 - 02 - 2016).

[2] ICE. The New Civil Engineer 2017; http://www.newcivilengineer.com/confirmation?www.newcivilengineer.com $\% 252$ fnew-definition-for-civil-engineering (assessed $17-02-2016$ )

[3] ASCE (2018) About Civil Engineering. American Society of Civil Engineers 2018; http://www.asce.org/about_civil_ engineering/ (assessed $12-01-2018$ )

[4] RAE. (2017) http://www.raeng.org.uk/education/vps/sustdev.htm 2017 (assessed 6- 10 - 2017).

[5] MEHTA, P. K. (2002). Greening of the concrete industry for sustainable development. Concrete International Vol. 24, No. 7, pp. 23 - 28.

[6] OCHSENDORF, J A. (2005) Sustainable engineering: the future of structural design, Structures. ASCE http://www.ascelibrary.org/

[7] SUHENDRO, B. (2014). Toward green concrete for better sustainable environment. Procedia Engineering Vol. 95, pp. $305-320$.

[8] SHAFIGH, P, MAHMUD, H. B, JUMAAT, M. Z, ZARGAR, M. (2014). Agricultural wastes as Aggregate in concrete mixtures - a review. Construction and Building Materials, Vol. 53, pp. 110 - 117.

[9] DEMIRBOGA, R., GÜL, R. (2006) Production of high strength concrete by use of industrial by- products. Building Environment, Vol. 41, pp. 1124-1127.

[10] DETWILER, R. J., FAPOHUNDA, C. A, NATALIE, J. (1994) Use of supplementary cementing materials to increase the resistance to chloride ion penetration of concrete cured at elevated temperatures. ACI Materials Journals, Vol. 91, No. 1, pp. $63-66$.

[11] ZELJKOVIC, M. (2009). Metakaolin effects on concrete durability. MSc. Thesis, University of Toronto, Canada.

[12] IBRAHIM, A. G., OKOLI, O. G.. DAHIRU, D. (2016). Comparative study of the properties of ordinary Portland cement concrete and binary concrete containing metakaolin mad from kankara kaolin in Nigeria. ATBU Journal of Environmental Technology, Vol. 9, No. 2, pp. 53 - 59.

[13] THOMAS M. (2007). Optimizing the use of fly ash in concrete. Portland Cement Association http://www.cement.org/docs/default-source/fc_concrete_technology/is548-optimizing-the-use-of-fly-ash-concrete.pdf, (assessed 1 - 1- 2017).

[14] FOONG, K. Y., ALENGARAM, U. J., JUMAAT, M.. Z. MO, K.H. (2015) Enhancement of the mechanical properties of lightweight oil palm shell concrete using rice husk ash and manufactured sand. Journal of Zhejiang University-SCIENCE A (Applied Physics \& Engineering), Vol. 16, No. 1, pp. 59 - 69. 
[15] FAPOHUNDA, C., AKINBILE, B, SHITTU A. (2017) Structure and properties of mortar and concrete containing rice husk ash as partial replacement of ordinary Portland cement - A review. International Journal of Sustainable Built Environment (In Press). http://dx.doi.org/10.1016/j.ijsbe.2017.07.004

[16] GHORPADE, V.G. (2012). Effect of wood waste ash on the strength characteristics of concrete. Nature Environment and Pollution Technology, Vol. 11, No. 1, pp. $121-124$.

[17] ELINWA, A. U. MAMUDA A. M. (2014). Sawdust ash as powder material for self-compacting concrete containing naphthalene sulfonate. Hindawi Publishing Corporation Advances in Civil Engineering, pp.1 - 8 . http://dx.doi.org/10.1155/2014/129276

[18] MCNEIL, K. KANG, T. H. (2013). Recycled concrete aggregates: A review. International Journal of Concrete Structures and Materials. Vol. 7, No. 1, pp. 61-69, DOI 10.1007/s40069-013-0032-5.

[19] ALENGARAM. U. J, MUHIT, B. J, JUMAAT, M. Z. (2013). Utilization of oil palm kernel shell lightweight aggregate in concrete - A review. Construction and Building Materials, Vol. 38, pp. 161-172.

[20] FAPOHUNDA, C. A, AKINSANYA, A. Y., ADEROJU, S. O. AND SHITTU, K. A. (2016). Suitability of crushed cow bone as partial replacement of fine aggregates for concrete production. The West Indian Journal of Engineering, Vol. 39, No. 1, pp. $25-31$.

[21] FAPOHUNDA. C. A, SHITTU, K. A, ADEROJU., S. O. AKINSANYA AY. (2016). Strength characteristics of concrete having crushed bone as partial replacement of fine aggregates at different water-cement ratios. Acta Technica Corniviensis - Bulletin of Engineering, Vol. 9, No. 1, pp. 162 - 169.

[22] GANIRON JR, T. U. (2014). Effect of sawdust as fine aggregate in concrete mixture for building construction. International Journal of Advanced Science and Technology, Vol. 63, pp. 73-82. http://dx.doi.org/10.14257/ijast.201 4.63.07

[23] RAHEEM, A.A., OLASUNKANMI, B. S. FOLORUNSO, C. S. (2012). Saw dust ash as partial replacement for cement in concrete. Organization, Technology and Management in Construction, Vol. 4, No. 2, pp. $474-480$.

[24] GARCIA, M., SOUSA-COUTINHO, J. (2013). Strength and durability of cement with forest waste bottom ash. Construction and Building Materials, Vol. 41, pp 897-910.

[25] OGORK, E. N., AYUBA, S. (2014). Influence of sawdust ash (sda) as admixture in cement paste and concrete. IJISET - International Journal of Innovative Science, Engineering \& Technology, Vol. 1, No. 10, pp. 736 - 743.

[26] SUBBARAMAIAH, G. (2016) Strength and durability studies on wood waste ash structural grade concrete. A PhD Thesis submitted to Jawaharlal Nehru Technological University Anantapur, Ananthapuramu, India. (http://shodhganga.inflibnet.ac.in/bitstream/.pdf assessed 6-10-2017).

[27] CHEAH, C. B., RAMLI, M. (2014). The implementation of wood waste ash as a partial cement replacement material in the production of structural grade concrete and mortar: an overview. Resource. Conserve. Recycle, Vol. 55, No. 7, pp. 669-685.

[28] CHOWDHURY S, MISHRA M, SUGANYA O. (2014). The incorporation of wood waste ash as a partial replacement material for making structural grade concrete: An Overview. Ain Shams Engineering Journal Vol. 6, pp. 429 - 437.

[29] PRUSTY, J. K, PATRO, S. K., BASARKAR, S. S. (2016). Concrete using agro-waste as fine aggregate for sustainable built environment.t - A review. International Journal of Sustainable Built Environment Vol. 5, pp. 312 - 333.

[30] JAHANGIRI, N, KOSEOGLU, K, CENGIZLER, H. (2017). Concrete with by-products and waste materials as aggregate or cement. Dicle University Institute of Natural and Applied Science Journal, Vol, 6, No. 1, pp. 29-38.

[31] ABDULLAHI, M. (2006). Characteristics of Wood ASH/OPC Concrete. Leonardo Electron J Pract Technol Vol. 8, pp. 9 - 16 .

[32] CHEAH, C. B, RAMLI, M. (2012). Mechanical strength, durability and drying shrinkage of structural mortar containing HCWA as partial replacement of cement. Construction and Building Materials, Vol. 30, pp. 320-329

[33] BERRA, M, MANGIALARDI, T, PAOLINI, A. E. (2015). Reuse of woody biomass fly ash in cement-based materials. Construction and Building Materials, Vol. 76, pp. 286-296.

[34] ETIEGNI, L, CAMPBELL, A. G. (1991). Physical and chemical characteristics of wood ash. Bioresource Technol, Vol. 37, No. 2, pp. 173-178

[35] NAIK, T. R, KRAUS, R. N, SIDDIQUE, R. (2002) Demonstration of manufacturing technology for concrete and utilizing wood ash from Wisconsin, Wisconsin Department of Natural Resources (Madison, WI) for project \#1-06 UWM report no. CBU-2002-30, Center for By-products Utilization, Department of Civil Engineering and Mechanics, University of Wisconsin-Milwaukee. 
[36] NAIK, T. R, KRAUS, R. N, SIDDIQUE, R. (2003). CLSM containing mixture of coal ash and a new pozzolanic material. ACI Materials Journals, Vol. 100, No. 3, pp. 208-15.

[37] UDOEYO, F. F, INYANG, H, YOUNG, D. T, OPARADU, E. E. (2006). Potential of wood ash waste as an additive in concrete. Journal of Materials in Civil Engineering, Vol. 18, No. 4, pp. 605-11

[38] ETTU, L.O, MBAJIORGU, M. S. W, NJOKU, F. C, AJOKU, C. A, NWACHUKWU, K. C. (2013) Strength variation of opc-saw dust ash composites with percentage saw dust ash. Civil and Environmental Research, Vol. 3, No. 9, pp.53 - 58.

[39] CHOWDHURY, S, MANIAR, A, SUGANYA, O. M. (2015). Strength Development in Concrete with Wood Ash Blended Cement and Use of Soft Computing Models to Predict Strength Parameters". Journal of Advanced Research, Vol. 6, pp. 907-913.

[40] NAIK, T. R, KRAUS, R. N. (2003). A new source of pozzolanic materials. Concrete International, 55-62.

[41] ABHISHEK, D. S, KUMBAR, P. K. (2017). An experimental study on durability aspects of concrete with partial replacement of cement by sawdust ash. International Journal of Scientific Research Organization Vol. 1, No. 5, pp. 36 - 41.

[42] CHEAH, C. B, PART, W. K, RAMLI, M. (2015). The hybridizations of coal fly ash and wood ash for the fabrication of low alkalinity geopolymer load bearing block cured at ambient temperature, Construction Building Material, Vol. 88, pp. 41-55.

[43] ADAMU, M, TIFASE, A. S, UCHE, O. A. U. (2017). Engineering properties of industrial wood waste ash-concrete. International Journal of Advances in Construction Engineering, Vol. 1, No. 1, pp. $1-10$.

[44] AWOLUSI, T. M, SOJOBI, A. O, AFOLAYAN, J. O. S. D. A (2017). and laterite applications in concrete: Prospects and effects of elevated temperature. Cogent Engineering. https://doi.org/10.1080/23311916.2017.1387954.

[45] RAHEEM, A. A, ADEDOKUN, S. I, AJAYI, B. R, ADEDOYIN, O, ADEGBOYEGA, B. O. (2017). Application of saw dust ash as partial replacement for cement in the production of interlocking paving stones. International Journal of Sustainable Construction Engineering \& Technology, Vol. 8, No. 1, pp. 1 - 11.

[46] KUMAR, T. R. P, SUDHEESH, C, SASI, K. S. (2015). Strength characteristics of saw dust ash based geopolymer concrete. International Journal of ChemTech Research, Vol. 8, No. 2, pp. 738-745.

[47] MARTHONG, C. (2012). Sawdust Ash (SDA) as partial replacement of cement". International Journal of Engineering Research and Applications, Vol. 2, No. 4, pp. 1980-1985.

[48] TYAGHER, S, UTSEV, J, ADAGBA, T. (2011). Suitability of saw dust ash-lime mixture for production of Sandcrete hollow blocks. Nigerian Journal of Technology, Vol. 30, No. 1, pp. 79-84

[49] MAGESWARI, M, VIDIVELLI, B. (2009). The use of sawdust ash as fine aggregate replacement in concrete. Journal of Environmental Research and Development, Vol. 3, No. 3, pp. 720-726.

[50] UDOEYO, F. F, DASHIBIL, P. U. (2002). Sawdust ash as concrete material. Journal of Materials in Civil Engineering, Vol. 14, No. 2, pp. 173-176.

[51] ASTM C618-05 (2005). Standard specification for coal fly ash and raw or calcined natural pozzolan for use as a mineral admixture in concrete. American Society for Testing and Materials International West Conshohocken Philadelphia.

[52] VASSILEV, S. V, BAXTER, D, ANDERSEN, L. K, VASSILEVA, C. G. (2010). An overview of the chemical composition of biomass. Fuel, Vol. 89, pp. 913-33.

[53] ELINWA A. U, MAHMOOD, A. M. (2002). Ash from timber waste as cement replacement material. Cement Concrete Composites, Vol. 24, 219-22.

[54] ELINWA, A. U, EJEH, S. P. (2004). Effects of incorporation of sawdust incineration fly ash in cement pastes and mortars. Journal of Asian Architecture Building Engineering, Vol. 3, No. 1, pp. 1-7.

[55] BS12. (1996). British Standards Institution -Specification for Portland Cement. British Standards Institution, London

[56] RAJAMMA, R, BALL, R. J, TARELHO, L.A.C, ALLEN, G. C, LABRINCHA, J.A, FERREIRA, V.M. (2009). Characteristics and use of biomass fly ash in cement-based materials. J Hazard Mater, Vol. 172, pp.1049-60.

[57] DEMIS, S, TAPALI, T. G, PAPADAKIS, V. G. (2014). An investigation of the effectiveness of the utilization of biomass ashes as pozzolanic materials. Construction and Building Materials, Vol. 68, pp. 291-300

[58] PAPADAKIS, V. G, ANTIOHOS, S, TSIMAS, S. (2002). Supplementary cementing materials in concrete - Part II: a fundamental estimation of the efficiency factor. Cement, Concrete and Research, Vol. 32, No. 10, pp. 1533 - 1538.

[59] ANTIOHOS, S. K, PAPADAKIS, V. G, CHANIOTAKIS, E, TSIMAS, S. (2007). Improving the performance of ternary blended cements by mixing different types of fly ashes. Cem Concr Res. Vol. 37, No. 6, pp. 877-85. 
[60] RAMOS, T, MATOS, A. M, SOUSA-COUTINHO, J. (2013). Mortar with wood waste ash: Mechanical strength carbonation resistance and ASR expansion. Construction and Building Materials, Vol. 49, pp. 343-351

[61] MEHTA, P. K, MONTEIRO, P. J. M. (2006). Concrete. microstructure, properties and materials McGraw-Hill, 3rd Edition.

[62] NEVILLE, A. M. (2011). Properties of concrete. Pearson Education Limited Edinburgh, England, 5th Edition. http://www.pearsoned.co.uk .

[63] MASSAZZA, F. (1998). LEA’S chemistry of cement and concrete. Peter C. Hewlett Arnold, 4th Edition.

[64] BS EN 196-1. (1995). Methods of testing cement. Physical tests. Strength tests. British Standard Institution, London.

[65] SHETTY, M. S. (2009). Concrete Technology. S. Chand and Company Ltd, New Delhi, MultiColour Edition.

[66] GAMBHIR, M. L. (2013). Concrete Technology - Theory and Practice. McGraw Hill Education Private Limited, New Delhi, 5th Edition.

[67] FALADE, F, IKPONMWOSA, E, AROGUNDADE, A. (2011). Investigation of some structural properties of foamed aerated concrete. Journal of Engineering Research, Vol. 16, pp. 67- 80

[68] ELLINWA, A. U, EJEH, S. P, AKAPABIO, I. O. (2005). Using metakaolin to improve sawdust ash concrete. Concrete International.

[69] BS 8110 (1997). Structural use of Concrete. British Standards Institution, London.

[70] MARTHONG, C. (2013). Size Effect Study of Sawdust Ash-Concrete under Compressive Load. IOSR Journal of Mechanical and Civil Engineering, Vol. 1, No. 5, pp. 27 - 32.

[71] ETTU, L. O, EZEH, J. C, ANYA, U. C, NWACHUKWU, K. C, NJOKU, K. O. (2013). Strength of ternary blended cement concrete containing afikpo rice husk ash and sawdust ash. International Journal of Engineering Science Invention, Vol. 2, No. 4, pp. $38-42$.

[72] ACI 318M-08 (2008). Building code requirements for structural concrete (ACI 318M-08) and commentary. American Concrete Institute.

[73] ASTM-C330 (2009). Standard specification for lightweight aggregates for structural Concrete. American Society for Testing and Materials International, Philadelphia.

[74] DAY, R. L. (1990). Pozzolans for use in low-cost housing - a state of the art report prepared for the international development research centre Ottawa, Canada International Development Research Centre, Ottawa.

[75] MHAISKAR, Y, NAIK, D. D. (2012). Studies on Correlation between Flexural Strength and Compressive Strength of Concrete, The Indian Concrete Journal, pp. 1 - 6.

[76] OLUOKUN, F. A. (1991). Prediction of concrete tensile strength from its compressive strength: Evaluation of existing relationship for Normal Weight Concrete. ACI Materials Journal, Vol. 88, No. 3, pp. 302 - 309.

[77] ATIS, C. D. (2005). Strength Properties of High-Volume Fly Ash Roller Compacted and Workable Concrete, and Influence of Curing Condition. Cement and Concrete Research, Vol. 35, pp. 1112 - 1121.

[78] JSCE (2007). Standard specifications for concrete structures, Materials and Construction. Japan Society of Civil Engineers, Vol. 7, pp. $10-11$.

[79] ACI Cомміттеe (2011). Building Codes Requirements for Structural Concrete. American Concrete Institute, Farmington Hills, Michigan.

[80] JACKSON, N, DHIR, R. K. (1990). Civil Engineering Materials, Macmillan London, 4th Edition.

[81] Patel, V. N. (209). Sorptivity testing to assess durability of concrete against freeze-thaw cycling. The Department of Civil Engineering and Applied Mechanics, McGill University, Montreal, Canada.

[82] SIDDIQUE, R. (2013). Compressive strength, water absorption, sorptivity, abrasion resistance and permeability of self-compacting concrete containing coal bottom ash. Constr. Build. Mater. Vol. 47, pp. 1444-1450.

[83] ASTM C1567-11 (2011). Standard test method for determining the potential alkali silica reactivity of combinations of cementitious materials and aggregate (accelerated mortar bar method). American Society for Testing and Materials International, Philadelphia.

[84] WANG, S, BAXTER, L. (2007). Comprehensive study of biomass fly ash in concrete: strength, microscopy, kinetics and durability. Fuel Process Technology, Vol. 88, pp. 1165-70.

[85] CHANG, C. F, CHEN, J. W. (2006). The experimental investigation of concrete carbonation depth. Cement and Concrete Research, Vol. 36, pp. 1760-1767. 
[86] WANG, S, LLAMAZOS, E, BAXTER, L, FONSECA, F. (2008). Durability of biomass fly ash concrete: freezing and thawing and rapid chloride permeability tests. Fuel, Vol. 87, pp. 359-64.

[87] ASTM C 1202 - 97 (1997). Standard test method for electrical indication of chloride's ability to resist chloride". American Society for Testing and Materials International, Philadelphia.

[88] AMRUTHA, G, NAYAK, M, NARASIMHAN, C, RAJEEVA, S. V. (2089). Chloride-ion Impermeability of self-compacting high-volume fly ash concrete mixes. Int. J. Civil Environ. Eng. Vol. 11, No. 4, pp.29 - 35.

[89] ACI 515.1 (1985). A guide to the use of waterproofing, damp proofing, protective, and decorative barrier systems for concrete, ACI Manual of Concrete Practice Masonry, Precast Concrete, Special Processes.

[90] BDEIR, L. M. H. (2012). Study some mechanical properties of mortar with sawdust as a partially replacement of sand. Anbar Journal for Engineering Sciences, Vol. 5, No. 1, pp. 22 - 30.

[91] KUMAR, D, SINGH, S, KUMAR, N, GUPTA, A. (2014). Low cost construction material for concrete as sawdust. Global Journal of Researches in Engineering, Vol. 14, No. 4, pp. 1 - 5.

[92] OLUTOGE, F. A. (2010) Investigations on sawdust and palm kernel shells as aggregate replacement. ARPN Journal of Engineering and Applied Sciences, Vol. 5, No. 4, pp. 7 - 13

[93] BOOB, T. N. (2014). Performance of saw-dust in low cost sandcrete blocks. American Journal of Engineering Research (AJER), Vol. 3, No. 4, pp. 197-206.

[94] OSEI, D. Y, JACKSON, E. N. (2016). Compressive strength of concrete using sawdust as aggregate. International Journal of Scientific \& Engineering Research, Vol. 7, No. 4, pp. 1349 - 1353.

[95] NARAYANAN, A, HEMNATH, G, SAMPAUL, K, MARY, A. (2017). Replacement of fine aggregate with sawdust. International Journal of Advanced Research in Basic Engineering Sciences and Technology, Vol. 3, No. 35, pp. 206 - 210.

[96] OKOROAFOR, S. U, IBEARUGBULAM, O. M, ONUKWUGHA, E. R, ANYAOGU, L, ADAH, E.I. Structural characteristics of sawdust-sand-cement composite. International Journal of Advancements in Research \& Technology, Vol. 6, No. 1, pp. $173-180$.

[97] OYEDEPO, O. J, OLUWAJANA, S. D, AKANDE, S. P. (2014). Investigation of properties of concrete using sawdust as partial replacement for sand. Civil and Environmental Research, Vol, 6, No.2, pp.35 - 42.

[98] ALBERT, M. J, AAYENA, K. J, ANJU, M. R, BOBINA, E. J. (2016). Partial replacement of fine aggregate with sawdust for concrete. International Journal for Technological Research in Engineering Vo. 3, No. 9, pp. 2439 - 2443.

[99] THANDAVAMOORTHY, T. S. (2015). Wood waste as coarse aggregate in the production of concrete. European Journal of Environmental and Civil Engineering.http://dx.doi.org/10.1080/19648189.2015.1016631

[100] BUTT, W. A, GUPTA, K, JHA J. N. (2016) Strength behaviour of clayey soil stabilized with saw dust ash. International Journal of Geo-Engineering, Vol. 7, No. 18, pp. 2 - 9.

[101] NIMYAT, P. S, TOK, Y. (2013). Effect of Saw Dust ash (SDA) Pozzolana on the Performance of Blended Cement Paste Concrete at High Temperatures. Civil and Environmental Research, Vo. 3, No. 11, pp. 22 - 28. 